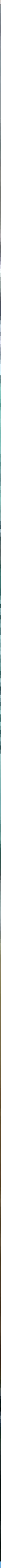

\title{
Pilot groepshuisvesting voedsters 2016
}





\section{Pilot groepshuisvesting voedsters 2016}

Jorine Rommers, Karel de Greef

Dit onderzoek is uitgevoerd door Wageningen Livestock Research en gesubsidieerd door het ministerie van Landbouw, Natuur en Voedselkwaliteit, in het kader van het Beleidsondersteunend onderzoek thema 'Gezondheid en Welzijn van Parkgehuisveste konijnen' (projectnummer: BO-47-001-016) binnen de PPS Innovatieprogramma Gezondheid en welzijn van parkgehuisveste konijnen (TKI-AF-15234) 
Rommers, J. K. de Greef, 2021. Pilot groepshuisvesting voedsters 2016. Wageningen Livestock Research, Openbaar Rapport 1302.

Samenvatting NL Dit rapport doet verslag van een serie van vijf opeenvolgende pilotproeven met beperkt aantal herhalingen die zijn uitgevoerd met betrekking tot parttime groepshuisvesting van voedsters in de commerciële konijnenhouderij. Hokindeling en daarmee de mogelijkheid voor voedsters om van elkaar weg/uit zicht te kunnen komen (vluchten) lijkt een belangrijke bijdrage te kunnen leveren in het verminderen en tijdig beëindigen van rangordestrijd tussen voedsters. Daarom zijn in de pilots verschillende hokindelingen onderzocht. Er is geëxperimenteerd met verschillende hokindelingen in zogenaamde combi-parken door het plaatsen van schotten onder en op het platform. Dit leek geen effect te hebben op het optreden van huidbeschadigingen en daarmee rangorde strijd tussen voedsters. In de hokken waarin naast de tussenwanden ook de nestkastafscheidingen waren verwijderd werden geen ernstig beschadigde voedsters aangetroffen. Hokindeling lijkt daarmee van invloed op het optreden van huidbeschadigingen. De pilots zijn echter met een beperkt aantal herhalingen uitgevoerd. De uitkomsten dienen daarom met enige voorzichtigheid te worden gehanteerd.

Summary UK In five successive pilot experiment different park layouts were tested with the objective to minimize skin injuries in group-housed rabbit does. Does were single housed in so called combi-parks. At 21 or 23 days of lactation the separations between six single parks were removed to create a group-park (combi-park system). The park layout was altered by changing the place of wooden panels underneath and up the platform. In this way different hide and escape routes were created. The panels between the nest boxes remained. In the fifth pilot also the panels between the nest boxes were removed creating a so called park that is also used in meat rabbits. In the parcs were the nest box panels were also removed no severe skin injuries were observed. Therefore, park layout seems to influence skin injuries. Results have to be treated with care, as the pilots were performed with small numbers and not repeated.

Dit rapport is gratis te downloaden op https://doi.org/10.18174/545254 of op www.wur.nl/livestock-research (onder Wageningen Livestock Research publicaties).

\section{(cc) BY-NC}

Dit werk valt onder een Creative Commons Naamsvermelding-Niet Commercieel 4.0 Internationaallicentie.

(C) Wageningen Livestock Research, onderdeel van Stichting Wageningen Research, 2021

De gebruiker mag het werk kopiëren, verspreiden en doorgeven en afgeleide werken maken. Materiaal van derden waarvan in het werk gebruik is gemaakt en waarop intellectuele eigendomsrechten berusten, mogen niet zonder voorafgaande toestemming van derden gebruikt worden. De gebruiker dient bij het werk de door de maker of de licentiegever aangegeven naam te vermelden, maar niet zodanig dat de indruk gewekt wordt dat zij daarmee instemmen met het werk van de gebruiker of het gebruik van het werk. De gebruiker mag het werk niet voor commerciële doeleinden gebruiken.

Wageningen Livestock Research aanvaardt geen aansprakelijkheid voor eventuele schade voortvloeiend uit het gebruik van de resultaten van dit onderzoek of de toepassing van de adviezen.

Wageningen Livestock Research is NEN-EN-ISO 9001:2015 gecertificeerd.

Op al onze onderzoeksopdrachten zijn de Algemene Voorwaarden van de Animal Sciences Group van toepassing. Deze zijn gedeponeerd bij de Arrondissementsrechtbank Zwolle. 


\section{Inhoud}

Woord vooraf $\quad 5$

$\begin{array}{ll}\text { Samenvatting } & 7\end{array}$

Summary (UK) $\quad 9$

$\begin{array}{ll}\text { Introductie } & 11\end{array}$

$\begin{array}{llr}1 & \text { Het pilot onderzoek } & 13\end{array}$

$\begin{array}{lll}1.1 & \text { Huisvesting } & 13\end{array}$

1.2 Dieren 13

1.3 Behandelingen 13

1.4 Waarnemingen $\quad 14$

$2 \quad$ Pilot 1 $r$

$\begin{array}{lll}2.1 & \text { Pilot 1: } 30 \text { juni - } 19 \text { juli } 2016 & 15\end{array}$

2.1.1 Indeling van het combi-park $\quad 15$

2.1.2 Aanvullende waarnemingen $\quad 16$

$\begin{array}{ll}2.1 .3 \text { Bevindingen } & 16\end{array}$

$\begin{array}{llr}3 & \text { Pilot } 2 & 18\end{array}$

3.1 Pilot 2: 20 september - 4 oktober $\quad 18$

3.1.1 Behandelingen 18

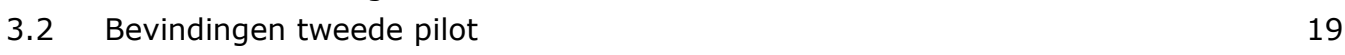

$\begin{array}{lll}3.3 & \text { Conclusies } & 21\end{array}$

4

$\begin{array}{ll}\text { Pilot } 3 & 22\end{array}$

4.1 Pilot 3: 2 november - 17 november $\quad 22$

$\begin{array}{ll}4.1 .1 & \text { Behandelingen }\end{array} 22$

$\begin{array}{lll}4.2 & \text { Conclusies } & 23\end{array}$

$\begin{array}{llr}5 & \text { Pilot } 4 & 24\end{array}$

5.1 Pilot 4: 15 december - 30 december 2016

$\begin{array}{ll}5.1 .1 \text { Behandelingen } & 24\end{array}$

$\begin{array}{lll}5.2 & \text { Conclusies } & 25\end{array}$

$\begin{array}{llr}6 & \text { Overall analyse } 4 \text { pilots } & 26\end{array}$

$\begin{array}{lll}6.1 & \text { Huidbeschadigingen } & 26\end{array}$

6.1.1 Naar onderdeel van het dier $\quad 26$

$\begin{array}{ll}6.1 .2 \text { Huidbeschadigingen per behandeling } & 27\end{array}$

$\begin{array}{lll}7.1 & 9 \text { maart - } 21 \text { maart } 2017 & 28\end{array}$

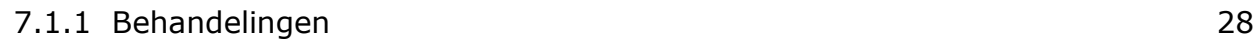

$\begin{array}{ll}7.1 .2 \text { Waarnemingen } & 28\end{array}$

$\begin{array}{ll}7.1 .3 \text { Huidbeschadigingen voedsters } & 29\end{array}$

$\begin{array}{ll}7.1 .4 \text { Uitval jongen } & 29\end{array}$

$\begin{array}{lll}7.2 & \text { Conclusies } & 29\end{array}$

$\begin{array}{lll}\text { 7.3 Aanbevelingen voor verder onderzoek } & 30\end{array}$

$\begin{array}{ll}\text { Referenties } & 31\end{array}$ 



\section{Woord vooraf}

Het houden van voedsters in semi-groepshuisvesting is een belangrijk punt in de PPS Duurzame konijnenhouderij. Het beperken van het (van nature voorkomende) beschadigende gedrag door voedsters onderling (rangordegevechten) is daarbij een van de grootste uitdagingen.

Om te onderzoeken of de rangordestrijd tussen voedsters, die leidt tot huidbeschadigingen, kan worden verminderd is pilotonderzoek uitgevoerd. In een vijftal korte opeenvolgende proeven zijn verschillende schuil- en vluchtmogelijkheden onderzocht. Doel was om te komen tot een hokindeling waarbij de voedsters goed van elkaar weg en uitzicht kunnen komen, waardoor geen ernstige huidbeschadigingen optreden.

Omdat het hier pilots betreft met een beperkt aantal herhalingen konden de resultaten niet statistisch getoetst worden en dienen daarom met terughoudendheid te worden geïnterpreteerd. Het onderzoek diende als vooronderzoek om de meest veelbelovende hoklay-out in nadien uitvoeriger te toetsen.

We zijn de familie Slegh erkentelijk voor het beschikbaar stellen van hun stallen, voor het uitvoeren van het dagelijks werk, het meedenken èn het daadwerkelijk bedenken en invullen van praktische oplossingen.

Dr. Ir. Karel de Greef projectleider 


\section{Samenvatting}

Dit rapport doet verslag van een serie van vijf opeenvolgende pilotproeven met beperkt aantal herhalingen die zijn uitgevoerd met betrekking tot parttime groepshuisvesting van voedsters in de commerciële konijnenhouderij. Rangordestrijd tussen voedsters is een belangrijk knelpunt om parttime groepshuisvesting van voedsters in op praktijkbedrijven te implementeren. Rangordestrijd uit zich in het ontstaan van huidbeschadigingen van voedsters. In dit onderzoek zijn huidbeschadigingen gescoord, en is de mate van beschadiging als afgeleide gebruikt voor het optreden van rangorde strijd/agressie tussen voedsters. Hokindeling en daarmee de mogelijkheid om van elkaar weg/uit zicht te kunnen komen (vluchten) lijkt een belangrijke bijdrage te kunnen leveren in het verminderen en tijdig beëindigen van rangorde strijd tussen voedsters. Daarom zijn in de pilots verschillende hokindelingen onderzocht. In de vier eerste pilots werd geëxperimenteerd met verschillende hokindelingen in zogenaamde combi-parken. Daarnaast zijn andere factoren, die van invloed kunnen zijn op de rangordestrijd tussen voedsters onderzocht, te weten: de meerwaarde van een crèche voor de voedsters en jongen, het tijdstip waarop de voedsters in de groep worden geplaatst ( 21 vs. 23 dagen lactatie), een lagere bezetting en de aanwezigheid van het eigen werphok in het park. In de vijfde pilot is onderzocht in hoeverre de nestkastafscheidingen, die in een combipark na het verwijderen van tussenwanden aanwezig blijven, mede debet is aan het optreden van ernstige huidbeschadigingen bij voedsters.

Samenvattend indiceren de pilots dat:

1. zowel het tijdstip warop voedsters in de groep worden geplaatst als het wel of niet handhaven van het eigen 'territorium in het park invloed heeft op het beschadigingen van voedsters. 2. Vanuit het oogpunt van groepshuisvesting verdient het in de groep plaatsen op 21 dagen na werpen de voorkeur boven 23 dagen na werpen. Voor de jongen is het echter niet gunstig als het in de groep komen samenvalt met het verwijderen van de nestkasten en daarom heeft voor hen mengen op 23 dagen de voorkeur.

3. Het handhaven van het eigen hok lijkt het risico op beschadigen te vergroten. Het verdient de voorkeur om de voedsters vanuit hun eigen werphok over te plaatsen naar een ander park, zodat het voormalig werphok niet meer aanwezig is.

4. In de hokken waarin naast de tussenwanden ook de nestkastafscheidingen is verwijderd werden geen ernstig beschadigde voedsters aangetroffen. Hokindeling lijkt daarmee van invloed op het optreden van huidbeschadigingen. 


\section{Summary (UK)}

In five successive pilot experiment different park layouts were tested with the objective to minimize skin injuries in group-housed rabbit does. In group housing aggressive behavior among rabbit does can cause (severe) skin injuries. Skin injuries can therefore be used to record the level of aggressive behavior among does. Does were single housed in so called combi-parks. At 21 or 23 days of lactation the separations between six single parks were removed to create a group-park (combi-park system). The park layout was altered by changing the place of wooden panels underneath the platform. In this way different hide and escape routes were created. The panels between the nest boxes remained. Groups existed of 4 or 6 multiparous hybrid rabbit does. Besides park layout also the presence of a nursery for the kits, the day of mixing ( 21 vs. 23 days after kindling), group size (four vs. six does) and the effect of removal of potential territory effects (the does' original area vs. transfer to another park) were tried out. In the fifth pilot also the panels in between the nest boxes were removed crating a so called park that is also used in meat rabbits. The results of the pilots indicate that the amount of skin injuries seems to be influenced by the day of mixing as well as the presence of a territory. From the ambitions of group housing, mixing at 21 days is preferred. However, this is at the same time as removing the nest boxes, causing cumulation of stress factors for the kits. Therefore, for the kits, mixing at 23 days is preferred over 21 days. Remaining in the original cage resulted in more skin injuries and therefore it is recommended to transfer does with kits to another (clean) group-park at mixing. Group size did not seem to influence skin injuries. Kits did not seem to benefit from a nursery. In the parcs were the nest box panels were also removed no severe skin injuries were observed. Therefore, park layout seems to influence skin injuries. Results have to be treated with care, as the pilots were performed with small numbers and not repeated. 


\section{Introductie}

Vanuit LTO is een meerjarenvisie opgesteld met als streven om te komen tot parttime groepshuisvesting van voedsters vanaf 2027. In het kader hiervan wordt door WLR-onderzoek uitgevoerd naar mogelijkheden van het huisvesten van voedsters in groepen en tot mogelijke oplossingen van knelpunten te komen.

Uit tot dusver onderzoek (Rommers en de Jong, 2005) is gebleken dat volledige groepshuisvesting, waarbij voedsters gedurende de gehele worpcyclus bij elkaar gehuisvest zijn, veel problemen met agressie geeft. Van nature graven voedsters een aparte werpgang om hun jongen in te werpen. Na werpen zoogt de voedster haar jongen gemiddeld eenmaal per 24 uur gedurende circa 3 minuten. Pas wanneer de jongen uit het nest komen (rond 2-3 weken leeftijd) worden de jongen in de groep geïntroduceerd. Om zoveel mogelijk tegemoet te komen aan de natuurlijke situatie wordt momenteel in het onderzoek gewerkt met een systeem waarbij voedsters het eerste deel van de lactatie (variërend van18 tot en met 23 dagen) individueel gehuisvest zijn. Pas vanaf 18-23 dagen worden voedsters met hun jongen in de groep geplaatst.

In eerder pilot onderzoek in 2014 op twee praktijkbedrijven zijn groepen van 4 voedsters met hun jongen in vleeskonijnenparken tezamen geplaatst vanaf 18 dagen na werpen. In deze pilotproef leek de agressie, gemeten aan de huidbeschadigingen van de voedsters, mee te vallen. Op basis van deze pilotproef lijkt het zinvol om in deze richting van onderzoek verder te gaan.

Het plaatsen in groepen op 18 dagen na werpen, bleek in het pilot onderzoek van 2014 voor de jongen te vroeg te zijn. Rond 18 dagen leeftijd beginnen de jongen zelf vast voer op te nemen, en zijn voor een groot deel nog afhankelijk van de moedermelk. Doordat de voedsters in de groep komen worden de jongen minder gezoogd dan als ze als worp bij de voedster in individuele hokken blijven gehuisvest (Rommers et al., 2012). Daarom zijn in de pilots van 2016 de voedsters op een later tijdstip na werpen in groepen geplaatst. In de pilot van 2014 was de uitval van de jongen tijdens de afmestfase hoog (25\%) en heeft daarom extra aandacht gehad in de pilots van 2016.

Groepshuisvesting van voedsters in een grondhok gaf te veel vervuiling en ergonomische omstandigheden lieten veel te wensen over. Daarom is overgeschakeld op mogelijkheden van groepshuisvesting in zogenaamde parken voor vleeskonijnen. Parken zijn hokken op werkhoogte van ongeveer 1,80 x 1 meter oppervlakte (de konijnen kunnen tenminste 3 opeenvolgende huppelsprongen maken), waarbij de ruimte is ingericht met een kunststofvloer, een platform, schuilmogelijkheden, vluchtmogelijkheden en verrijking in de vorm van knaaghout en ruwvoer. De hokken zijn open aan de bovenkant waardoor de konijnen zich vrij kunnen oprichten. De vraag is of in dergelijke parken groepshuisvesting van voedsters mogelijk is.

Daartoe zijn dit jaar op het proefbedrijf in pilot setting verschillende hokindelingen en andere factoren, die van invloed kunnen zijn op de agressie uitgetest in zogenaamde combi-parken. In een combi-park kunnen zowel voedsters als vleeskonijnen worden gehouden, waardoor de jongen bij spenen niet hoeven te worden verplaatst naar een ander park. Uit voorgaand onderzoek bij WLR is gebleken dat de hokindeling een belangrijke factor kan zijn in het tegen gaan van agressie (Rommers et al., 2014) Immers wanneer voedsters bij een confrontatie voldoende mogelijkheden hebben om weg te vluchten en uit zicht te verdwijnen kan een agressieve interactie worden gestopt. Daarom is de hokindeling op basis van de bevindingen in vier opeenvolgende pilots aangepast. Daarnaast zijn een aantal factoren in de pilots uitgetest, die mogelijk van belang kunnen zijn voor het voorkomen van agressie en de daarmee gepaard gaande huidbeschadigingen van voedsters en jongen. De belangrijkste vragen zijn: wat is de meerwaarde van een crèche voor de voedsters en jongen, is de leeftijd waarop de voedsters in de groep worden geplaatst van invloed op het optreden van agressie, geeft een lagere bezetting minder agressie en geeft de aanwezigheid van het eigen werphok in het park meer agressie doordat de voedster haar eigen territorium verdedigt. In een vijfde pilot is tenslotte het combi-park vergeleken met een regulier park voor vleeskonijnen op optreden van huidbeschadigingen en uitval van de jongen na spenen. 
Doel van deze pilotproeven was om te komen tot een optimale hokindeling en inzicht te krijgen in het effect van de genoemde factoren op het beschadigen van voedsters.

Doordat het pilot onderzoek betreft met een beperkt aantal herhalingen per behandeling, kunnen de data niet statistisch worden geanalyseerd. In dit rapport wordt achtereenvolgens verslag gedaan van de vijf opeenvolgende pilots. 


\section{$1 \quad$ Het pilot onderzoek}

Het pilot onderzoek is uitgevoerd op het proefbedrijf van de familie Slegh. Dit bedrijf heeft ongeveer 600 voedsters met nakomelingen en daarbij behorende vleeskonijnen. Het onderzoek is afwisselend uitgevoerd in 2 identieke afdelingen ( 528 voedsters/afdeling), uitgerust met combi-hokken. In de combi-hokken kunnen voedsters individueel gehuisvest kunnen worden. Door het verwijderen van de tussenwanden van 6 hokken wordt een park gecreëerd waarin de voedsters met hun jongen gezamenlijk kunnen worden gehouden. Bij spenen worden de voedsters uit het park gehaald en overgezet in schone hokken waar ze weer individueel gehouden worden tot 21-23 dagen na werpen van de volgende worp. De speenkonijnen blijven in het park tot en met slachtleeftijd (ongeveer 11 weken). Het park is dus zowel voor voedsters als voor vleeskonijnen te gebruiken (combi). Voordeel van dit systeem is dat er all-in/all-out gewerkt kan worden. Eenmaal in de 12 weken (6 weken zoogperiode, 6 weken afmestperiode) komen de parken leeg en kunnen geheel worden gereinigd.

\section{$1.1 \quad$ Huisvesting}

Op dit bedrijf worden combi-hokken gebruikt. In een afdeling stonden 4 dubbele rijen met elk 66 welzijnshokken of 11 parken per rij. In een dubbele rij waren de hokken ruggelings aan elkaar geplaatst. Er zijn maximaal 9 parken per pilot gebruikt.

\subsection{Dieren}

Het onderzoek is uitgevoerd met 144 meerdere worps voedsters (hybride: Hycole). Dit is de groep waarbij de minste problemen worden verwacht. De voedsters hebben meer dan één geworpen en zijn ervaren met het grootbrengen van jongen. De jongen zijn groter/zwaarder als eerste worps voedsters en zullen daarmee mogelijk minder problemen hebben in een groepshok. De voedsters zijn op ongeveer 11 dagen na werpen geïnsemineerd, dit betekent dat het overgrote deel van de voedsters dragend en zogend was tijdens het onderzoek.

\subsection{Behandelingen}

Zoals aangegeven in de introductie zijn in de opeenvolgende pilots verschillende factoren die mogelijk van invloed kunnen zijn op het optreden van agressie, uitgetest. Het betroffen: het tijdstip (leeftijd van de jongen) waarop de voedsters in de groep worden geplaatst ( 21 vs. 23 dagen), het aantal voedsters per park (4 vs. 6), wel of geen crèche voor de in het groepshok, het wel of niet in stand blijven van het eigen werphok in het park (territorium). 
Tabel 1 geeft een overzicht van de behandelingen met het aantal parken per behandeling in de vier opeenvolgende pilots.

Tabel 1 Overzicht van de behandelingen met het aantal combi-parken per behandeling in de vier pilots.

\begin{tabular}{|c|c|c|c|c|c|c|c|c|c|}
\hline Pilot & 1 & 2 & & & 3 & & 4 & & \\
\hline $\begin{array}{l}\text { Leeftijd in groep, } \\
\text { dagen }\end{array}$ & $21 \mathrm{~d}$ & $21 \mathrm{~d}$ & $23 d$ & $23 d$ & $23 d$ & $23 d$ & $23 \mathrm{~d}$ & $23 d$ & Totaal \\
\hline Bezetting, n & 6 & 6 & 6 & 6 & 4 & 6 & 4 & 4 & \\
\hline $\begin{array}{l}\text { Behandeling } \\
\text { Crèche }\end{array}$ & met & zonder & met & zonder & zonder & zonder & zonder & zonder & \\
\hline $\begin{array}{l}\text { Behandeling } \\
\text { territorium }\end{array}$ & eigen & eigen & eigen & eigen & eigen & eigen & eigen & vreemd & \\
\hline Aantal parken & 2 & 2 & 2 & 2 & 3 & 3 & 3 & 3 & 20 \\
\hline Aantal voedsters & 12 & 12 & 12 & 12 & 12 & 18 & 12 & 12 & 102 \\
\hline
\end{tabular}

In de vijfde pilot zijn in totaal 42 meerdere worps drachtige voedsters verdeeld over 3 combi-parken (met 4 voedsters per park) en 6 vleeskonijnenparken ( 3 met 4 voedster/park en 3 met 6 voedsters per park). In alle parken waren zonder crèche en alle voedsters zijn bij mengen geplaatst in een vreemd park.

\subsection{Waarnemingen}

1. Huidbeschadigingen: Uit voorgaand onderzoek bij WLR (Rommers et al., 2011) is gebleken dat het scoren van huidbeschadigingen een goede indicatie is van de mate van agressie die tussen voedsters optreedt. Wanneer voedsters in een groep worden geplaatst zal er altijd enige agressie optreden omdat de rangorde in de groep moet worden vastgesteld. Echter na ongeveer 3 dagen moet de rust in het hok zijn weergekeerd. De voedsters zijn daarom rond dag 3 na plaatsen in de groep en bij spenen beoordeeld op huidbeschadigingen.

De huidbeschadigingen zijn gescoord op basis van de volgende scores: $0=$ onbeschadigd, $1=$ licht; oppervlakkige beschadiging (kras), 2= matig; beschadiging dieper dan een oppervlakkige kras maar nog geen wond, 3=ernstig; wond. De scores 0 en 1 kunnen worden gezien als geen of lichte beschadigingen die binnen enkele dagen genezen, de scores 2 en 3 zijn ernstigere beschadigingen waarvan het langer dan enkele dagen duurt voordat ze genezen zijn (Kalle, 1994)

De volgende delen van het lichaam zijn gescoord: kop, oren, lijf, staart, poten en vulva.

2. Uitval: de uitval van de jongen vanaf plaatsing in de groep tot en met spenen is geregistreerd. Daarnaast is ook de dagelijkse uitval in de afmestperiode gevolgd, omdat in voorgaand onderzoek een hoge uitval bij de vleeskonijnen werd geconstateerd. 


\section{$2 \quad$ Pilot 1}

\subsection{Pilot 1: 30 juni - 19 juli 2016}

Proefbehandeling: vanaf 23 dagen in de groep met een crèche voor de jongen (totaal 12 voedsters in 2 combi-parken).

\subsubsection{Indeling van het combi-park}

In eerste instantie is er gekozen voor een jongen crèche in het combi-park. De crèche is een door gaas afgescheiden deel van het park waarbij het gaas $5 \mathrm{~cm}$ boven de bodem is geplaatst, zodat de jongen eronderdoor kunnen en de voedsters niet. Deze jongen crèche geeft de jongen de mogelijkheid om zich eventueel terug te trekken (bijv. wanneer er voedsters in het park aan het vechten gaan). Nadeel van een crèche is dat er minder ruimte voor de voedsters over blijft en doordat de voedsters geen toegang tot de crèche hebben en dat achterblijvers/zieke jongen mogelijk onvoldoende melk krijgen, doordat ze in de crèche blijven zitten.

Daarnaast zijn er drie schotten geplaatst en een pvc-buis onder het plateau om de voedsters de mogelijkheid te geven om zich eventueel achter/in te verschuilen en bij onrust snel uit zicht te kunnen komen. De schotten waren zowel in de lengte als dwars onder het plateau geplaatst (zie hokindeling 1 en afbeelding 1). Het plateau is $40 \mathrm{~cm}$ breed en loopt over de lengte richting van het park op $25 \mathrm{~cm}$ boven het vloeroppervlak. Er was stro (in de vorm van een geperste rol) aanwezig als extra verrijking.

Hokdeling 1:
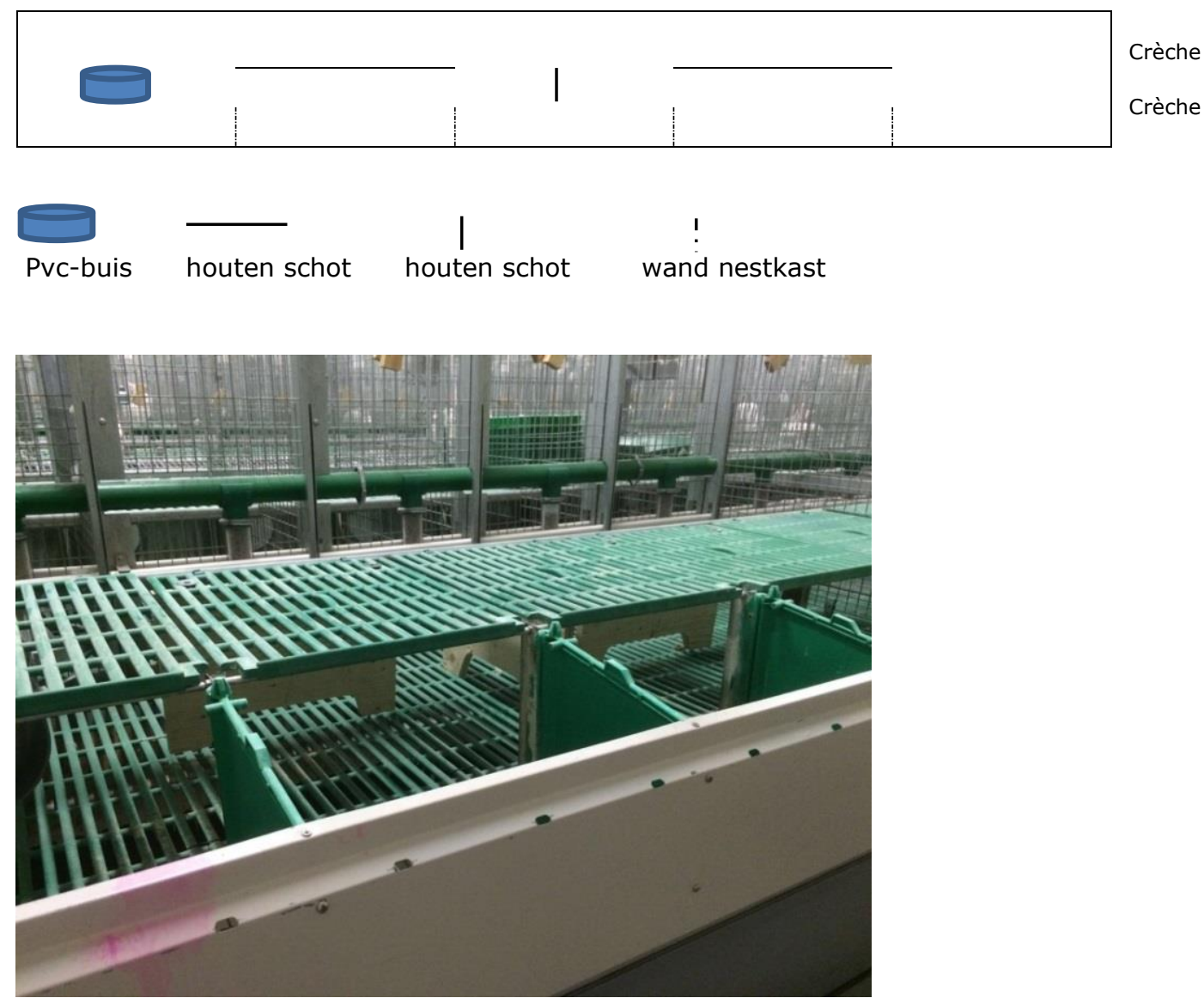

Afbeelding 1 Combi-park met schotten in lengte en dwarsrichting onder het platform en crèche (aan rechtereinde van het park).

De dieren zijn alleen 4 dagen na plaatsing in de groep beoordeeld op huidbeschadigingen. 


\subsubsection{Aanvullende waarnemingen}

Aan de hand van directe gedragsobservatie (een uur nadat de dieren in de groep waren geplaatst) gedurende een uur gekeken hoeveel agressieve interacties optraden en of de voedsters makkelijk van elkaar weg konden komen. Tijdens de directe observatie zijn gelijktijdig video-opnamen gemaakt gedurende de eerste twee uren na plaatsing in de groep, omdat dan de meeste agressieve interacties worden verwacht en hieruit kan worden afgeleid of voedsters voldoende van elkaar weg kunnen komen en de hokindeling voldoet of niet.

\subsubsection{Bevindingen}

1. Hokindeling

In de eerste ronde, waarin de schotten gedeeltelijk in de lengte richting van het park waren opgesteld bleek de hokopstelling niet optimaal, zowel voor de dieren als voor de verzorging. Schotten in de lengterichting geven onvoldoende onderbreking voor de voedsters en maakt voor de verzorging dat men er niet achter kan kijken, waardoor dode dieren niet worden gezien.

De crèche leek geen meerwaarde te hebben, konijntjes liepen veel in het groepsdeel en er zijn geen bijzonderheden waargenomen m.b.t. beschadigingen aan de jongen bij spenen. Het weglaten van de crèche geeft meer bewegingsruimte voor de voedsters.

\section{Huidbeschadigingen en gedragsobservaties}

Er kwamen matige en ernstige beschadigingen voor, met name op het lijf (zie figuur 1 ). In een combipark was 1 dier ernstig beschadigd (open wond), en 2 dieren matig beschadigd (diepere krassen in de huid; zie Tabel 1). In het tweede hok waren 2 dieren matig beschadigd. Beschadigingen worden met name gezien op het lijf en de oren. Dit komt overeen met de bevindingen van ander onderzoek. Voedsters die vechten benaderen elkaar of frontaal waarbij kop en oren beschadigd raken of van achteren waarbij met name de achterkant van het lijf beschadigd wordt.

Uit de directe observaties leek niet dat voedsters zich vastliepen in het park maar dat er behoorlijk wat aanvallen gevolgd door verjagen te zien waren. Directe agressie in de vorm van bijten werd niet waargenomen. Ook op de videobanden werden geen directe vechtpartijen waargenomen. De jongen leken voldoende ruimte in het park te hebben en niet in de knel te komen wanneer er agressieve interacties plaats vond. De gedragsobservaties leverden weinig additionele informatie op en waren arbeidstarief, waardoor besloten werd, deze waarnemingen in de volgende pilots niet meer uit te voeren.

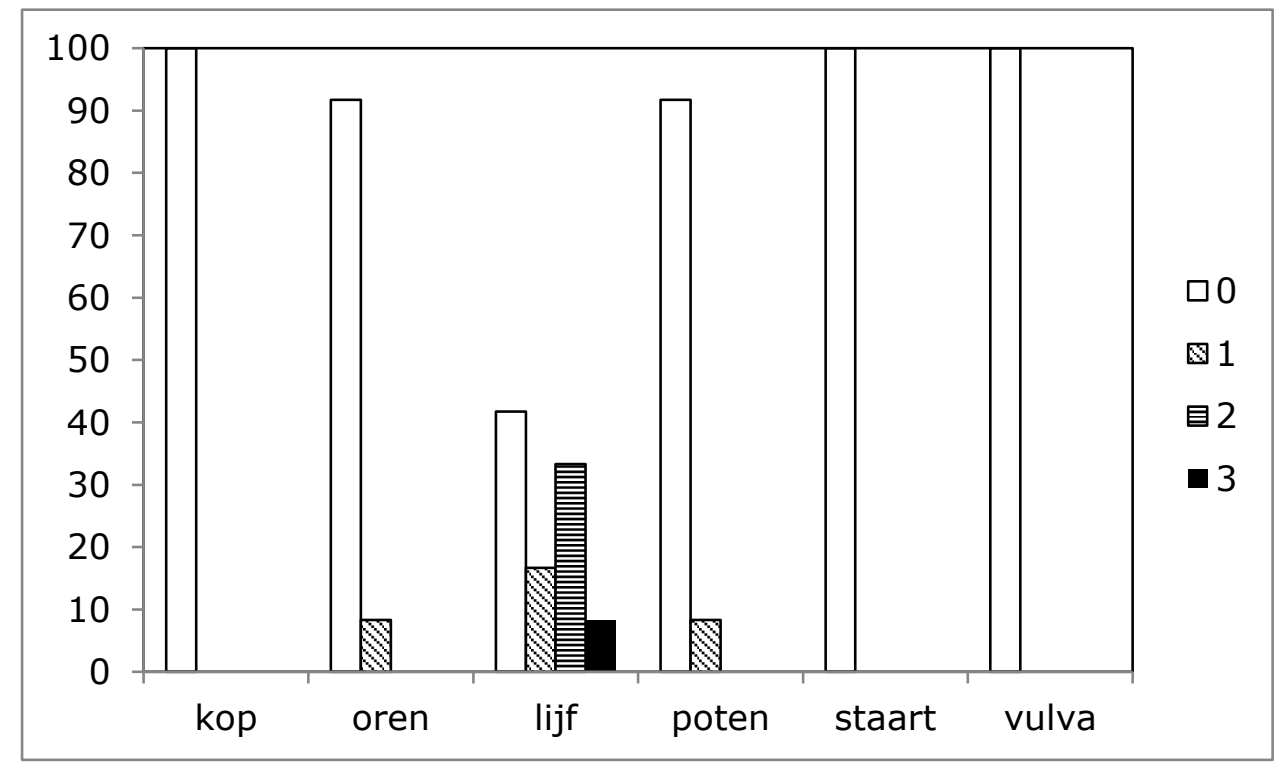

Figuur 1 Huidbeschadigingen enkele dagen na plaatsen in de groep. Score $0=$ geen, score $1=l i c h t$, score 2 = matig, score $3=$ ernstig 
Tabel 2 Overzicht van het aantal beschadigde dieren en ernst van de huidbeschadigingen naar plaats op het dier in pilot 1.

\begin{tabular}{lllll} 
Score huidbeschadiging & geen & oppervlakkig & matig & ernstig \\
Oren & 11 & 1 & 0 & 0 \\
\hline Lijf & 5 & 2 & 4 & 1 \\
\hline Poten & 11 & 1 & 0 & 0 \\
\hline
\end{tabular}

3. De uitval van de jongen tijdens het afmesttraject

Tijdens het afmesttraject zijn er geen jongen uitgevallen en ook waren er geen achterblijvers bij afleveren. 


\section{$3 \quad$ Pilot 2}

\subsection{Pilot 2: 20 september - 4 oktober}

Het doel van de tweede pilot was om het aantal beschadigde voedsters te reduceren door aanpassingen aan de parkindeling. In deze ronde zijn 6 parken met 6 meerdere worpsvoedsters per park (totaal 36 voedsters) ingezet. Deze pilot was aanvullend op de eerste pilot. In de verwerking van de data wordt daarom een overzicht gegeven van 4 behandelingen

\subsubsection{Behandelingen}

a) Dezelfde indeling van het park als vorige pilot zonder crèche op 23 dagen leeftijd in de groep (2 parken)

b) Andere indeling (beter zicht) van het park met crèche op 21 dagen in de groep (2 parken)

c) Indeling als onder c maar dan zonder crèche en op 21 dagen in de groep (2 parken)

Hokindeling 2:

a) Idem als hokindeling 1

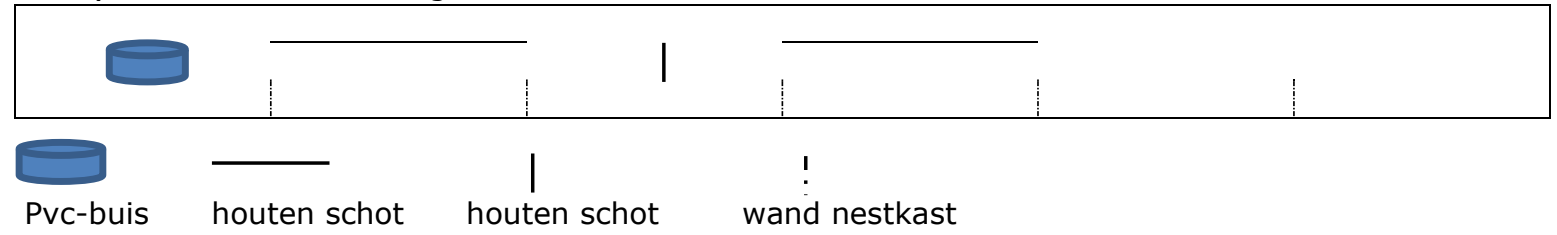

b)

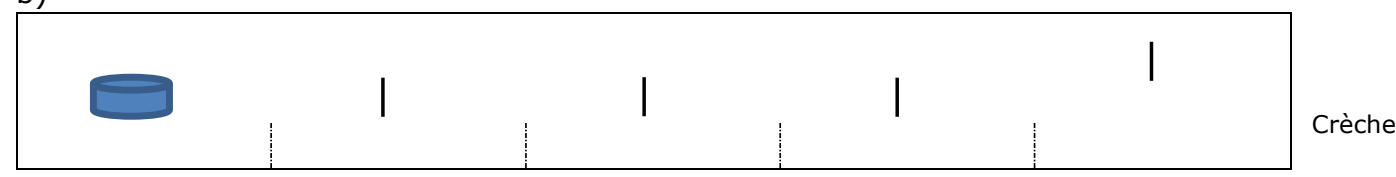

C)

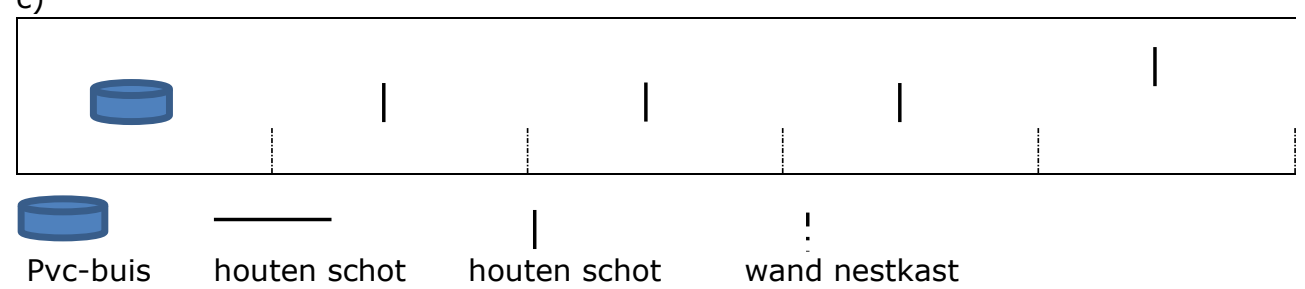




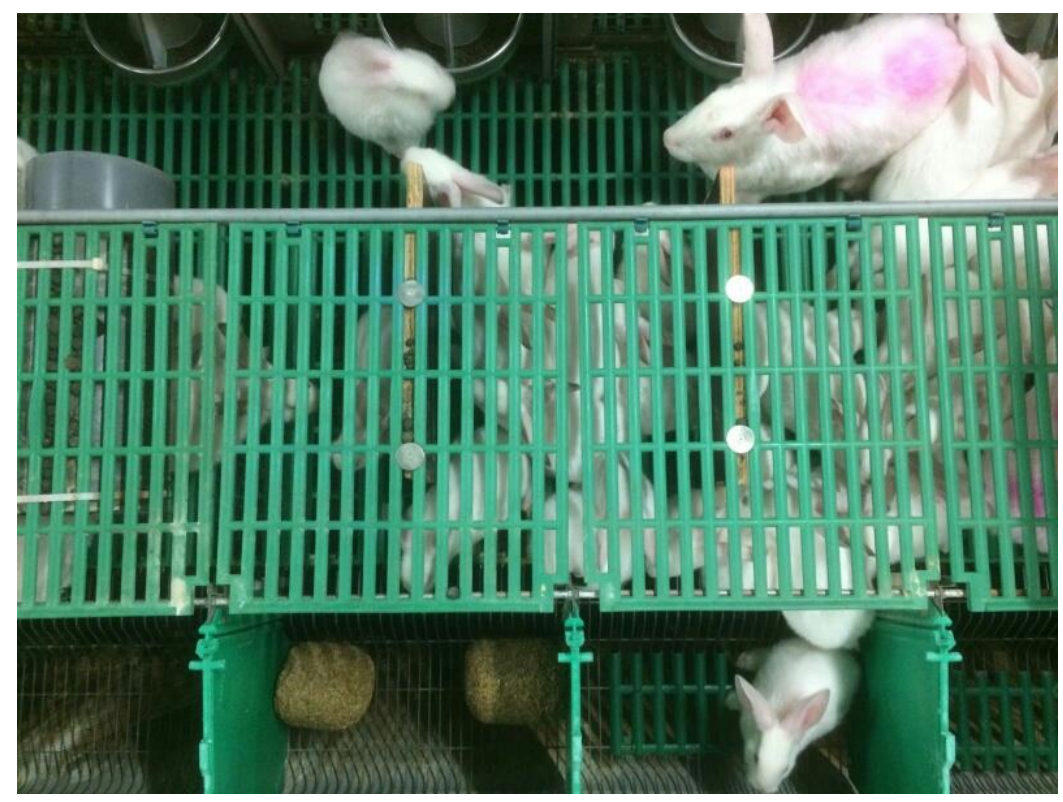

Afbeelding 2 Dwarsschotten en pvc-pijp onder het plateau.

\subsection{Bevindingen tweede pilot}

1. Hokindeling

De hokindeling, waarbij alleen dwarsschotten onder het plateau waren geplaatst, gaf beter overzicht voor de verzorging en leek de voedster meer mogelijkheden te bieden om weg te komen. Echter het plateau blijft een groot vlak waarop voedsters elkaar achter na kunnen zitten. Mogelijk helpt het als er een dicht schot op plateau wordt gezet, waardoor voedsters uit zicht kunnen komen.

2. Huidbeschadigingen

Er werden geen directe vechtpartijen direct na plaatsen van de voedsters in de groepen waargenomen door de konijnenhouder. Er werden matig en ernstig beschadigde voedsters waargenomen zowel 4 dagen na plaatsing in de groep als bij spenen, waarbij de ernstig beschadigde voedster (score 3) ook mager (benadeeld) was met spenen (zie figuur 2 en tabel 2). Er was 1 voedster die na plaatsen een ernstige verwonding had in behandeling d23 met crèche. Mogelijk is de hokbezetting te hoog. In een volgende pilot lijkt het zinvol om naast de bezetting van 6 voedsters/park ook 4 voedsters in een park te plaatsen.

\section{Tijdstip van mengen}

Het plaatsen in de groep op 21 dagen leeftijd is te vroeg voor de jongen op dit bedrijf. Dit is de leeftijd waarop op de nestkasten worden weggehaald om de opname van vast voer te stimuleren. De jongen moeten hun weg in de kooi leren te vinden, ze zijn te onbekwaam om dan gelijk in een groepshok te worden geplaatst (persoonlijke mededeling Slegh). Op dit bedrijf verdient 23 dagen de voorkeur boven 21 dagen. 


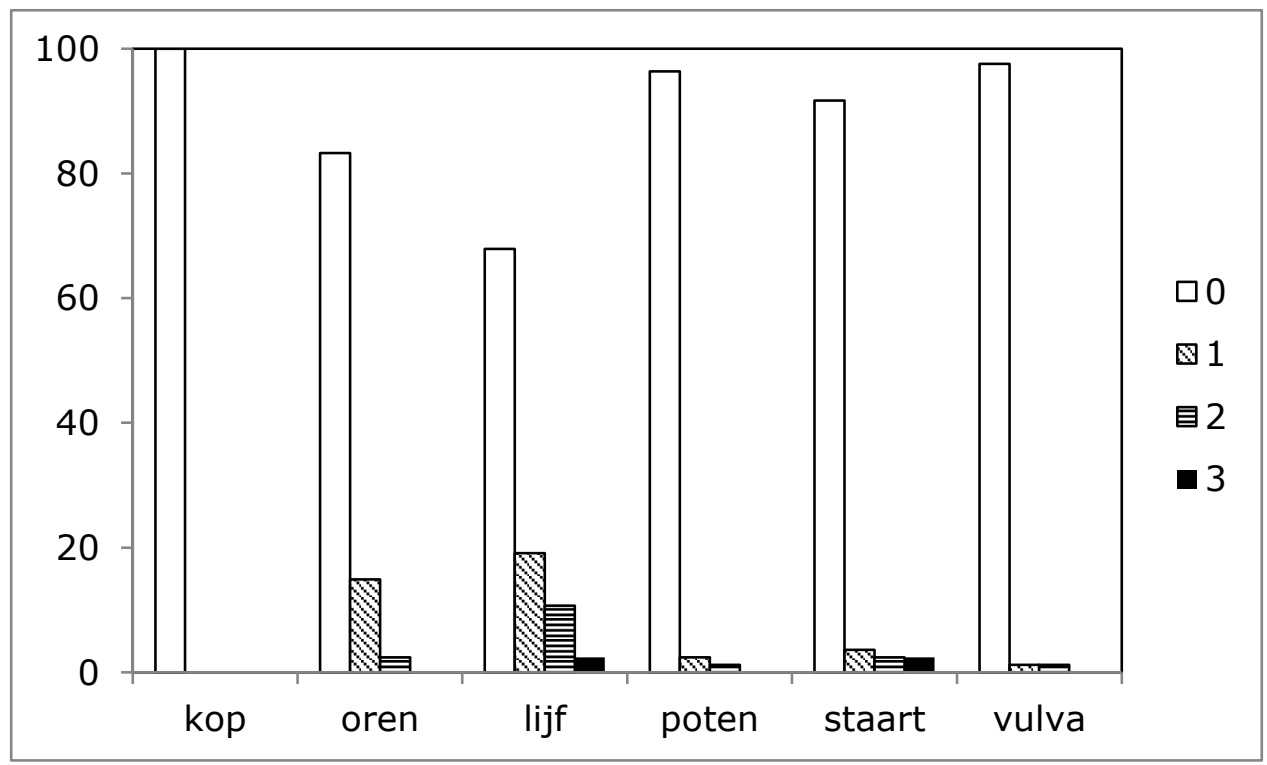

Figuur 2 Huidbeschadigingen (\%) totaal (na plaatsen en bij spenen) over de behandelingen naar plaats op het dier waar de beschadigingen werden aangetroffen. Score $0=$ geen, $1=$ licht, $2=$ matig en $3=$ ernstig.

Tabel 3 Overzicht van het aantal beschadigde voedsters aan het lijf en ernst van de beschadiging.

\begin{tabular}{|c|c|c|c|c|}
\hline Score huidbeschadiging & geen & oppervlakkig & matig & ernstig \\
\hline $4 \mathrm{~d}$ na mengen & 26 & 6 & 3 & 1 \\
\hline Bij spenen & 26 & 8 & 2 & 0 \\
\hline
\end{tabular}

4. De uitval van de jongen voor spenen (in groep) en tijdens het afmesttraject

Tabel 4 Uitval van de jongen voor (in groep) en na spenen.

\begin{tabular}{|c|c|c|c|c|}
\hline Behandeling & $\begin{array}{c}\text { uitval } \\
\text { mengen- spenen }\end{array}$ & $\begin{array}{c}\text { Uitval } \\
\text { Na spenen }\end{array}$ & Achterblijvers & Totaal na spenen \\
\hline $\mathrm{d} 21$ & 0 & 0,0 & 0 & 0,0 \\
\hline d21creche & 0 & 2,4 & 0 & 2,4 \\
\hline d21creche & 3,8 & 4,8 & 0 & 4,8 \\
\hline d23 & 1,9 & 0,0 & 0 & 0,0 \\
\hline
\end{tabular}

De uitval voor spenen bedroeg voor $\mathrm{d} 211,0 \%$, voor $\mathrm{d} 21 \mathrm{creche} 1,9 \%$ en voor $\mathrm{d} 232,1 \%$

De totale uitval na spenen bedroeg voor d21 2,4\%, voor d21creche 3,6\% en voor de d23 2,4\% 


\subsection{Conclusies}

1. Er zijn ernstig beschadigde voedsters. Hokindeling aanpassen door het plaatsen van een dicht schot op het platform, zodat de voedsters op het platform uit zicht kunnen komen

2. De crèche lijkt geen meerwaarde te hebben, maar beperkt wel de bewegingsruimte voor de voedsters. In de volgende pilot geen crèche meer in het park plaatsen.

3. Vanuit het oogpunt van huidbeschadigingen verdient het plaatsen van de voedsters in de groep op 21 dagen na werpen de voorkeur boven 23 dagen na werpen. Echter vanuit het oogpunt van de jongen valt 21 dagen na werpen in de groep plaatsen samen met het verwijderen van de nestkasten op dit bedrijf. Dit verdient niet de voorkeur.

4. De hokbezetting is mogelijk te hoog. In de volgde pilot lijkt het zinvol om naast zes ook vier voedsters per park te plaatsen.

5. De uitval van de jongen zowel voor als na spenen geven geen aanwijzing dat zich problemen voor doen. 


\section{$4 \quad$ Pilot 3}

\subsection{Pilot 3: 2 november - 17 november}

Doel: verminderen van het aantal matig en ernstig beschadigde voedsters door aanpassing parkindeling en verlagen van de bezetting. De voedsters zijn op dag 23 na werpen in de groep geplaatst.

\subsubsection{Behandelingen}

a) 6 voedsters per park (3 parken)

b) 4 voedsters per park (3 parken)

De hokindeling was aangepast door in alle parken een dicht dwarsschot op het plateau te plaatsen (zie afbeelding 3). Onder het plateau was de indeling gelijk aan ronde 2-afbeelding c (met alleen dwarsschotten en ronde buis). Er was geen crèche meer aanwezig in de parken.

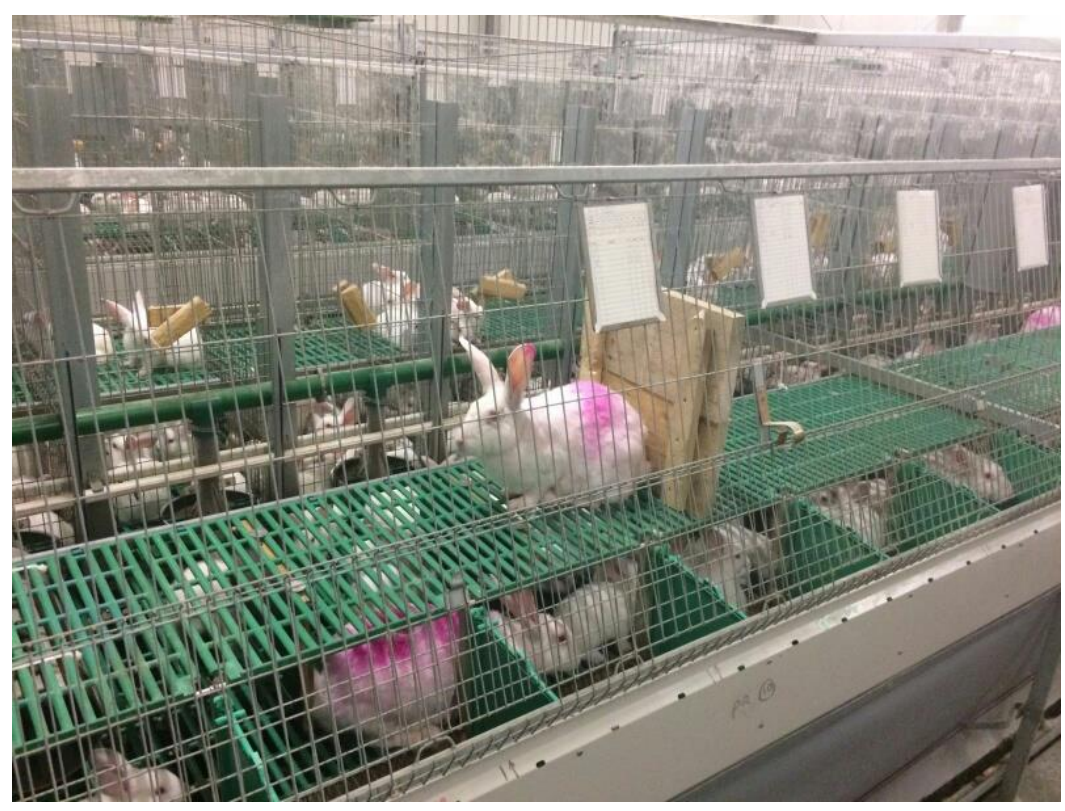

Afbeelding 3 Dwarsschotten en PVC pijp onder het plateau met één dwarsschot op het plateau.

\section{Hokindeling}

De hokindeling gaf geen problemen vanuit oogpunt van controle en werkbaarheid. Voedsters lijken voldoende uit zicht te kunnen komen.

\section{Huidbeschadigingen}

De huidbeschadigingen werden ook hier met name op het lijf geconstateerd. Na plaatsing in de groep werden er 3 voedsters met ernstige verwondingen aangetroffen, zowel bij een bezetting van 4 dieren per park ( 1 voedster) als bij 6 dieren per park ( 2 voedsters). Bij spenen werden alleen nog lichte beschadigingen aangetroffen. Hieruit blijkt dat de matig en ernstige huidbeschadigingen vrijwel geheel kunnen genezen. 


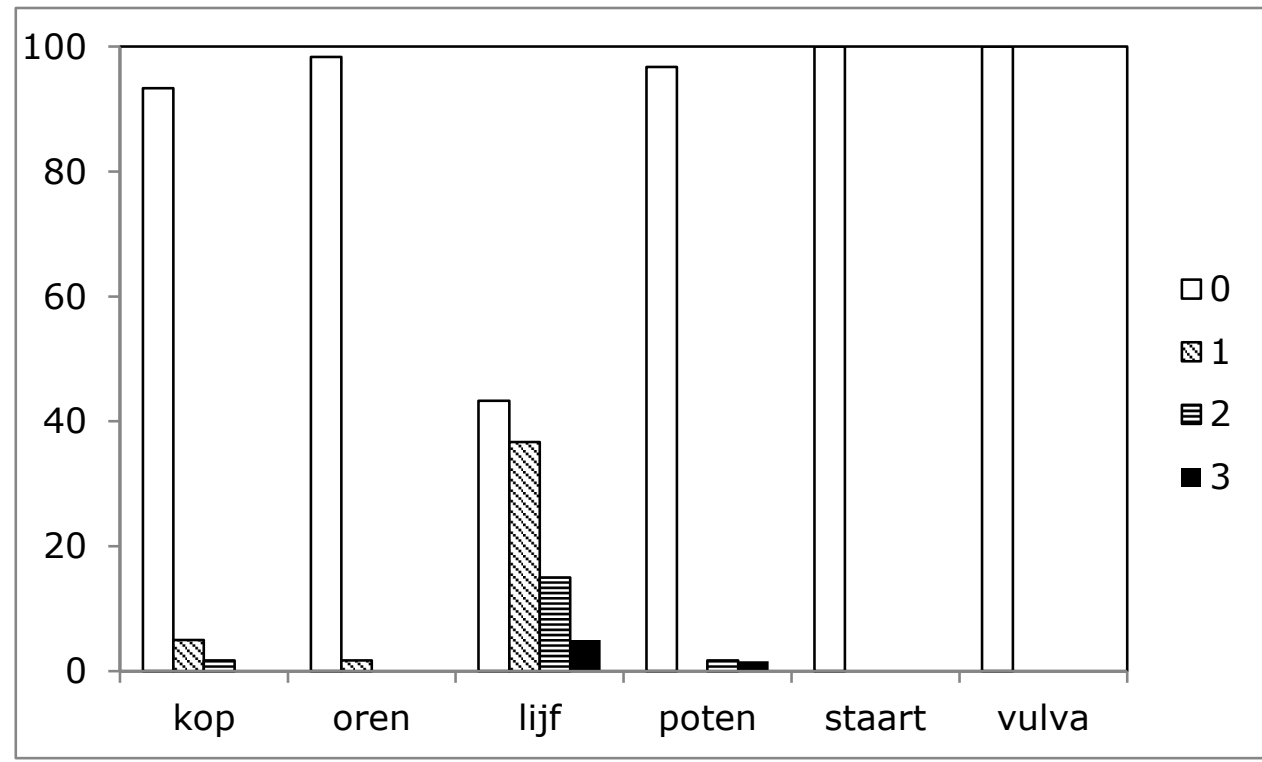

Figuur 4 Huidbeschadigingen (\%) totaal (na plaatsen en bij spenen) over de behandelingen naar plaats op het dier waar de beschadigingen werden aangetroffen. Score $0=$ geen, $1=$ licht, $2=$ matig en $3=$ ernstig.

Tabel 5 Ernst van de huidbeschadigingen op het lijf (in \% van het totaal aantal dieren per behandeling) enkele dagen na plaatsen in de groep en bij spenen.

\begin{tabular}{llllll} 
& Aantal & Na plaatsen & & Bij spenen & Matig-ernstig \\
$\begin{array}{l}\text { Ernst } \\
\text { huidbeschadigingen }\end{array}$ & Geen-licht & Matig-ernstig & Geen-licht & \\
\hline 4 voedsters/park & 12 & 66,7 & 33,3 & 100 & 0 \\
\hline 6 voedsters/park & 18 & 55,6 & 44,4 & 100 & 0 \\
\hline
\end{tabular}

3. Uitval van de jongen voor spenen (in groep) en tijdens het afmesttraject

Tabel 6 Uitval van de jongen voor spenen (in groep) en na spenen.

\begin{tabular}{|c|c|c|c|}
\hline & Voor spenen & Na spe & \\
\hline$d 23-4$ & 2,4 & 2 & 7,1 \\
\hline d23-4 & 0 & 0 & 0 \\
\hline d23-4 & 2,4 & 0 & 2,4 \\
\hline$d 23-6$ & 4,8 & 1 & 7,1 \\
\hline d23-6 & 2,4 & 0 & 2,4 \\
\hline
\end{tabular}

Uitval voor d23-4 bedroeg na spenen $3,2 \%$ en voor $d 23-6$ 7,1\%.

\subsection{Conclusies}

1. Het verlagen van de bezetting van 6 naar 4 voedsters per park geeft nog steeds ernstige verwondingen, alleen het aantal voedsters dat het betreft was minder. Alleen het terug brengen van de bezetting lijkt onvoldoende.

2. De uitval van de jongen geven geen aanleiding om aan te nemen dat zich ernstige problemen voor doen bij de jongen zowel voor als na spenen. 


\section{$5 \quad$ Pilot 4}

\subsection{Pilot 4: 15 december - 30 december 2016}

Er zijn in totaal 6 parken met 4 drachtige voedsters met hun jongen per park ingezet.

De parkindeling was gelijk aan pilot 3, dwz dwarsschotten en 1 pvc pijp onder en één schot boven op het platform en geen creche (zie afbeelding 3 ).

\subsubsection{Behandelingen}

1. Drie parken tussenwanden weghalen (=het eigen werphok blijft in het park in stand; territorium in het park) (3 parken).

2. Voedsters van drie parken verhuizen naar een ander park (=voedsters worden overgeplaatst naar een vreemd park en hebben dus geen territorium in het park; 3 parken)

1. Hokindeling

Geen nieuwe bevindingen. Hokindeling gaf voedsters de mogelijkheid om te vluchten of uit zicht te komen van hun belagers.

2. Huidbeschadigingen

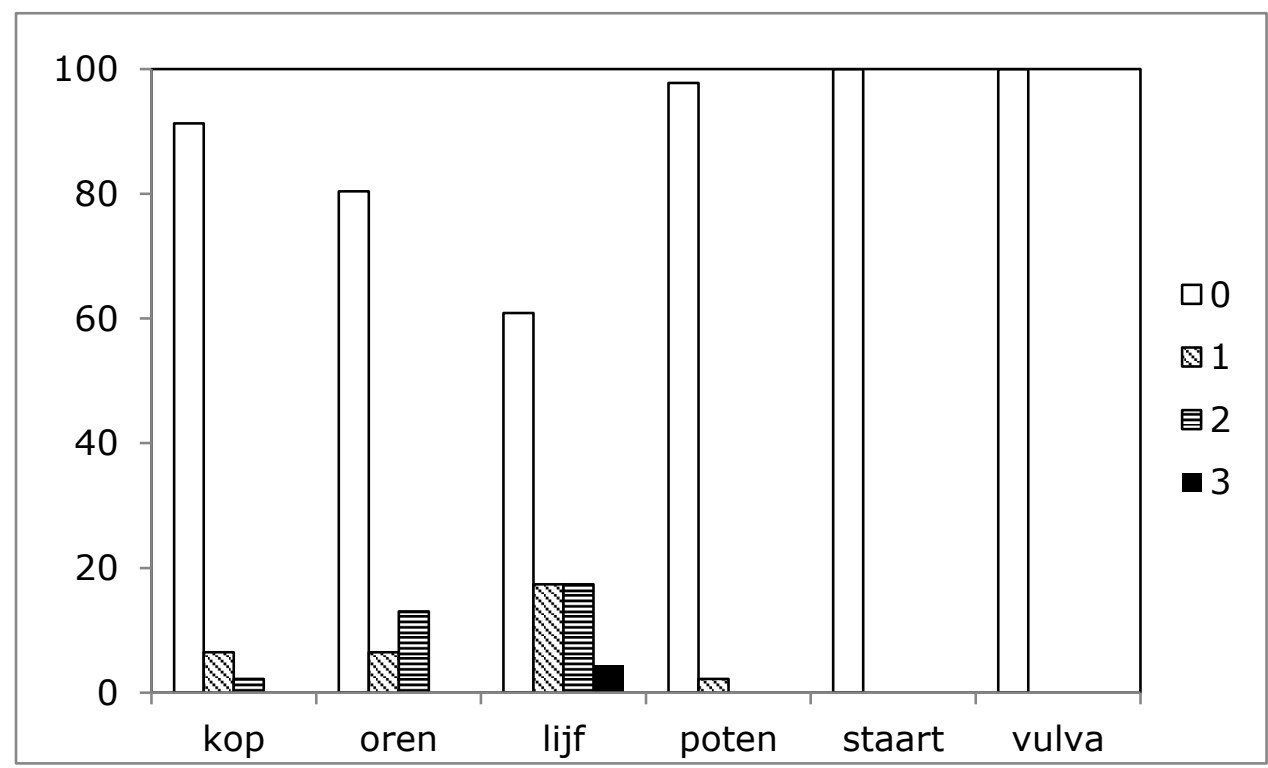

Figuur $5 \quad H u i d b e s c h a d i g i n g e n(\%)$ total (na plaatsen en bij spenen) over de behandelingen naar plaats op het dier waar de beschadigingen werden aangetroffen. Score $0=$ geen, $1=$ licht, $2=$ matig en $3=$ ernstig.

Tabel 7 Ernst van de huidbeschadigingen op het lijf (in \% van het totaal aantal dieren per behandeling) enkele dagen na plaatsen in de groep en bij spenen.

\begin{tabular}{llllll} 
& Aantal & \multicolumn{2}{l}{ Na plaatsen } & & Bij spenen \\
& voedsters & \multicolumn{2}{c}{} & & \\
Ernst beschadiging & & Geen-licht & Matig-ernstig & Geen-licht & Matig-ernstig \\
\hline Zonder territorium & 12 & 81,8 & 18,2 & 81,8 & 18,2 \\
\hline Met territorium & 12 & 83,3 & 16,7 & 66,7 & 33,3 \\
\hline
\end{tabular}


De huidbeschadigingen worden met name aan lijf, kop en oren waargenomen. Bij 1 voedsters (met territorium) werd een ernstige verwonding aangetroffen (score 3). Uit het percentage beschadigde voedsters per behandeling blijkt dat bij spenen er meer matig-ernstig beschadigde voedsters waren bij de parken waarin de voedsters een territorium hadden dan in de parken waar de voedsters geen territorium hadden. Een eigen territorium (het voormalige werphok) in het park lijkt dus niet de voorkeur te hebben.

3. Uitval van de jongen voor spenen en tijdens het afmesttraject

Tabel $8 \quad$ Uitval van de jongen voor spenen (in groep) en na spenen.

\begin{tabular}{|c|c|c|c|c|}
\hline \multicolumn{3}{|c|}{ Voor spenen } & \multicolumn{2}{|c|}{ Na spenen } \\
\hline d23eigen & 0 & 2,4 & 0 & 2,4 \\
\hline d23eigen & 2,7 & 0 & 0 & 0 \\
\hline d23eigen & 0 & 7,1 & 0 & 7,1 \\
\hline d23vreemd & 0 & 4,8 & 0 & 4,8 \\
\hline d23vreemd & 5,6 & 0 & 0 & 0,0 \\
\hline
\end{tabular}

Uitval voor spenen bedroeg voor d23eigen: 0,9 en na spenen $3,2 \%$

Uitval voor spenen bedroeg voor d23vreemd: 1,9 en na spenen $2,4 \%$

\subsection{Conclusies}

1. Een territorium in het park lijkt risico op huidbeschadigingen te geven.

2. Groepshuisvesting lijkt geen problemen te geven voor de jongen gezien de lage uitval zowel voor als na spenen. 


\section{Overall analyse 4 pilots}

\subsection{Huidbeschadigingen}

\subsubsection{Naar onderdeel van het dier}

Figuur $6 a$ en $6 \mathrm{~b}$ geeft een overzicht van de beschadigingen van de verschillende delen van het dier die zijn gescoord enkele dagen na plaatsen in de groep (a) en bij spenen (b) gemiddeld over de eerste 4 pilots.

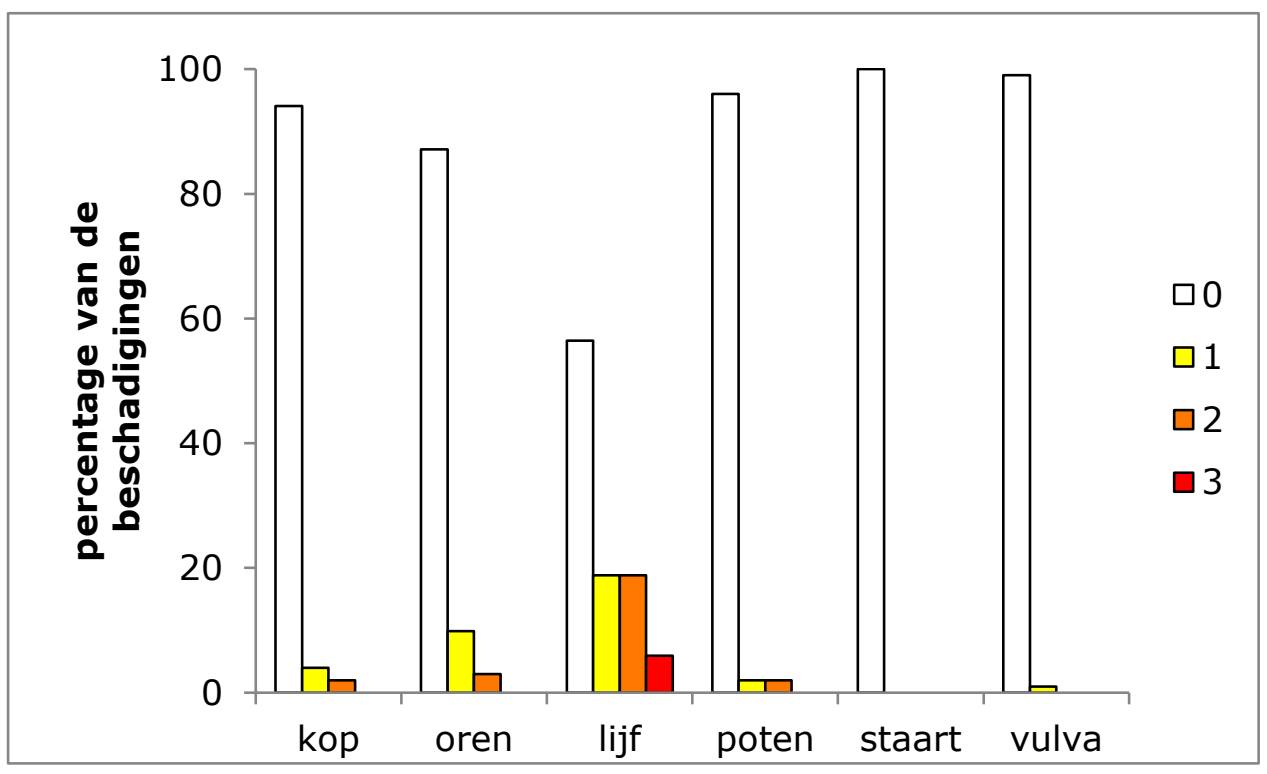

Figuur 6a Overzicht van de beschadigingen per lichaamsdeel enkele dagen na plaatsing in de groep. 0 =onbeschadigd, $1=$ licht beschadigd, $2=$ matig beschadigd, $3=$ ernstig beschadigd.

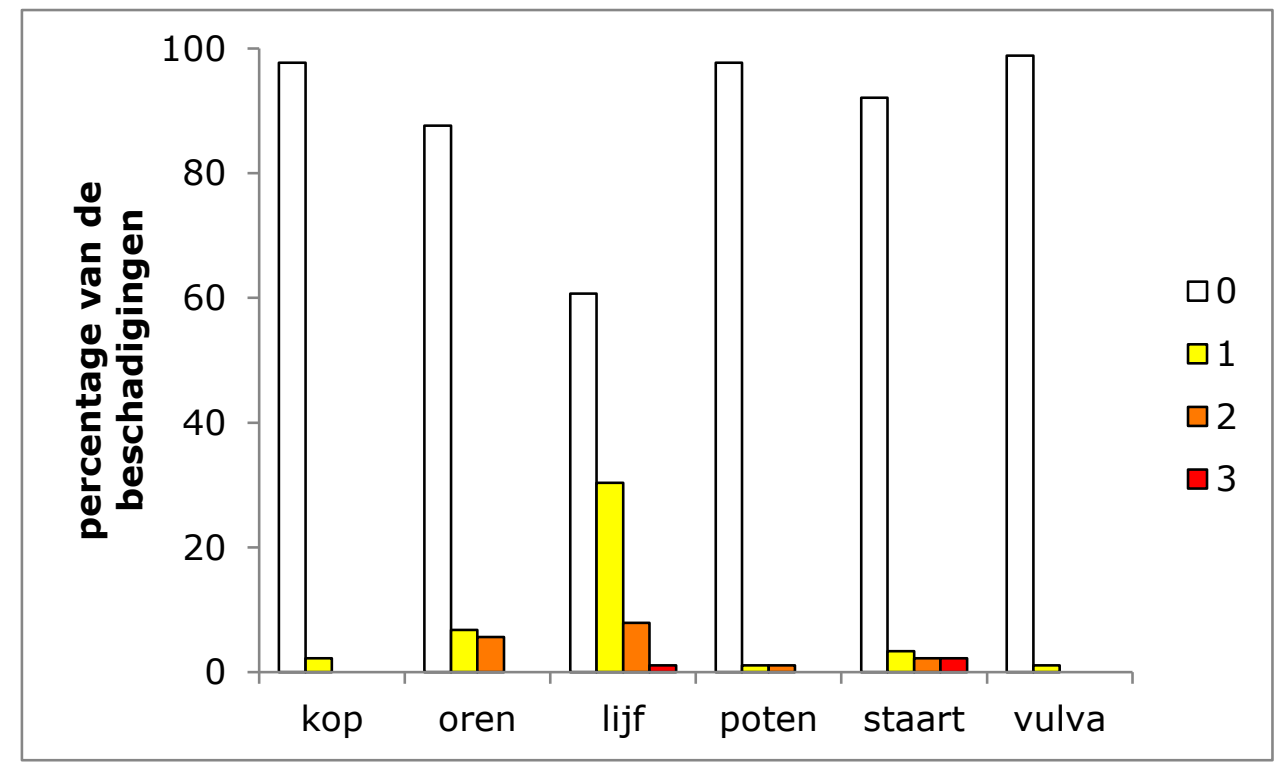

Figuur $6 \boldsymbol{b}$ Overzicht van de beschadigingen per lichaamsdeel bij spenen. $0=$ onbeschadigd, $1=$ licht beschadigd, 2= matig beschadigd, $3=$ ernstig beschadigd.

Uit figuur $6 a$ en $6 \mathrm{~b}$ blijkt dat het met name het lijf is dat beschadigd raakt. Daarom hebben we ons in de verdere uitwerking van de gegevens beperkt tot het lijf. 


\subsubsection{Huidbeschadigingen per behandeling}

Voor de effecten bezetting (4 of 6 dieren/park) en creche (met/zonder) was het mogelijk om resultaten van de vier rondes tezamen te bekijken. Deze behandelingen kwamen voor in meerdere pilots (zie tabel 1 ).

\section{a. Bezetting}

Tabel 9 Overzicht van het percentage beschadigde dieren bij een bezetting van 4 of 6 dieren per park na plaatsen en bij spenen naar ernst van de beschadiging.

\begin{tabular}{llllll}
\multicolumn{2}{c}{$\begin{array}{c}\text { Aantal } \\
\text { parken }\end{array}$} & Na plaatsen & \multicolumn{2}{c}{ Bij spenen } \\
Ernst beschadiging & & Geen-licht & Matig-ernstig & Geen-licht & Matig-ernstig \\
\hline 4 & 9 & 77,1 & 22,9 & 82,9 & 27,1 \\
\hline 6 & 11 & 74,2 & 25,8 & 96,3 & 3,7 \\
\hline
\end{tabular}

b. Creche

Tabel 10 Overzicht van het percentage beschadigde dieren dat in een park met of zonder creche heeft gezeten na plaatsen en bij spenen naar ernst van de beschadiging.

\begin{tabular}{llllll}
\multicolumn{2}{c}{$\begin{array}{c}\text { Aantal } \\
\text { parken }\end{array}$} & Na plaatsen & \multicolumn{2}{c}{ Bij spenen } \\
Ernst beschadiging & & Geen-licht & Matig-ernstig & Geen-licht & Matig-ernstig \\
\hline Met & 4 & 79,2 & 20,8 & 91,7 & 8,3 \\
\hline zonder & 16 & 74,0 & 26,0 & 90,9 & 9,1 \\
\hline
\end{tabular}

Uit de figuren 6 a en $6 \mathrm{~b}$ en de tabellen 9 en 10 blijkt dat enkele dagen na plaatsing in de groep het aantal beschadigde dieren hoger ligt dan dat bij spenen is gescoord. Dit komt overeen met eerder onderzoek waarin de agressieve interacties tussen voedsters is gescoord in de eerste dagen na plaatsen in de groep. Na enkele dagen bleken de interacties beduidend minder te worden (Rommers et al., 2011).

Uit de tabel 9 blijkt dat meer ruimte (4 dieren vs. 6 dieren/park) geen duidelijke invloed heeft op het verminderen van het percentage matig tot ernstig beschadigde dieren. De verdeling van het percentage beschadigde dieren, zowel na plaatsen als bij spenen, blijft vrijwel gelijk. Dit was buiten de verwachting. Aangenomen werd dat bij een lagere bezetting (4 dieren/park) de dieren meer ruimte hebben om van elkaar weg te komen en meer afstand van elkaar kunnen nemen, waardoor minder beschadigingen op treden.

Uit tabel 7 blijkt dat het niet overplaatsen van de voedsters naar een ander park (eigen) met name bij spenen een hoger percentage matig tot ernstig beschadigde dieren geeft. Enkele dagen na plaatsing in de groep is dit percentage echter vrijwel gelijk voor de dieren in eigen of in vreemd park. In ander onderzoek op dit bedrijf (Rommers et al., 2014) bleek het hebben van een eigen territorium in dit park weinig invloed te hebben op de beschadigingen. Zowel bij de controle als de proefbehandeling werden huidbeschadigingen waargenomen.

Samenvattend, op basis van de vier bovenbeschreven pilots, kan worden geconcludeerd dat:

1. Zowel het tijdstip waarop voedsters in de groep worden geplaatst als het wel of niet hebben van een eigen territorium in het park invloed heeft op het beschadigingen van voedsters.

2. Vanuit het oogpunt van gropeshuisvesting verdient het in de groep plaatsen op 21 dagen na werpen de voorkeur boven 23 dagen na werpen. Voor de jongen is het echter niet gunstig als het in de groep komen samenvalt met het verwijderen van de nestkasten.

3. Het hebben van een eigen territorium lijkt het risico op beschadigen te vergroten. Het verdient de voorkeur om de voedsters vanuit hun eigen werphok over te plaatsen naar een ander park, zodat het voormalig werphok niet meer aanwezig is. ]

4. Echter het aantal beschadigde voedsters met ernstige beschadigingen blijft aanwezig. Mogelijk vormen de nestkastafscheidingen, die in het combihok aanwezig blijven, een obstakel om goed weg te kunnen komen van een achtervolger. 


\section{$7 \quad$ Pilot 5}

\subsection{9 maart - 21 maart 2017}

In de vijfde pilot is tenslotte geëxperimenteerd met het weghalen van de nestkastafscheidingen die normaliter intact blijven in het combihok, nadat de tussenwanden zijn verwijderd. Hierdoor ontstaat een park, zoals voor vleeskonijnen wordt gebruikt.

\subsubsection{Behandelingen}

1. 3 parken met nestkastschotten (met 2 schotten en een PVC buis onder het plateau, géén schot op het plateau!) met 4 voedsters per park

2. 3 parken zonder nestkastschotten (met pvc buis en 2 schotten onder het plateau, geen schot op het plateau) met 4 voedsters per park (zie afbeelding 4 )

3. 3 parken zonder nestkastschotten (met pvc buis en 2 schotten onder het plateau, geen schot op het plateau) met 6 voedsters per park

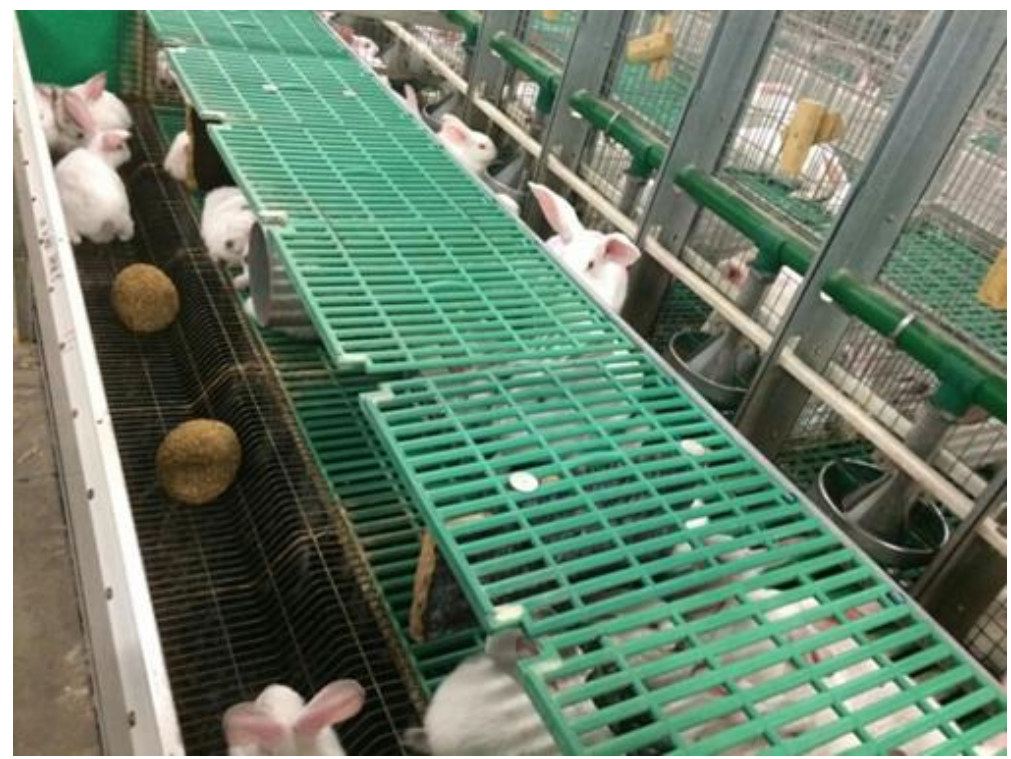

Afbeelding 4 Combipark zonder nestkastafscheidingen.

Er was geen crèche voor de jongen in de hokken. Alle voedsters met hun jongen zijn naar een ander (vreemd) hok overgeplaatst. De voedsters waren alle meerdere worps voedsters en werden op 23 dagen lactatie in de groep geplaatst (tot en met spenen op 35 dagen leeftijd).

\subsubsection{Waarnemingen}

Alle voedsters zijn op vier dagen na plaatsen in de groep/mengen en vlak voor spenen beoordeeld op huidbeschadigingen aan de hand van dezelfde scoringsmethode als gehanteerd in de voorgaande vier pilots. 


\subsubsection{Huidbeschadigingen voedsters}

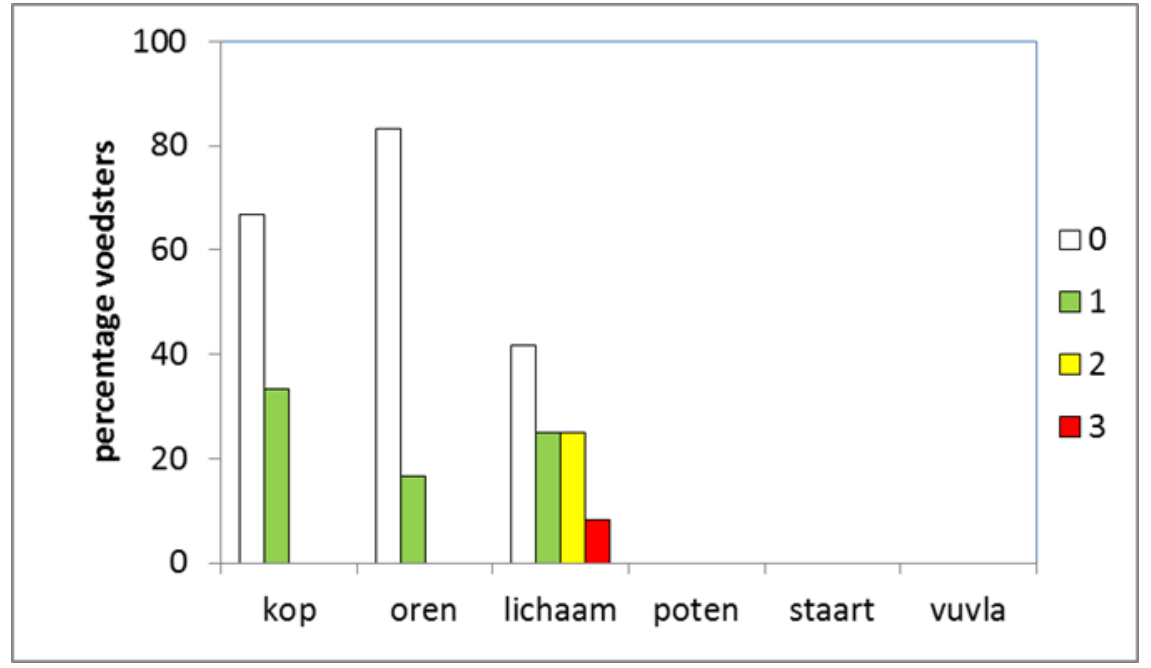

Figuur 7a Huidbeschadigingen 4 dagen na mengen in combiparken met nestkastafscheidingen. ( 0 =geen, 1 =oppervlakkig, 2=matig, 3= open wonden.

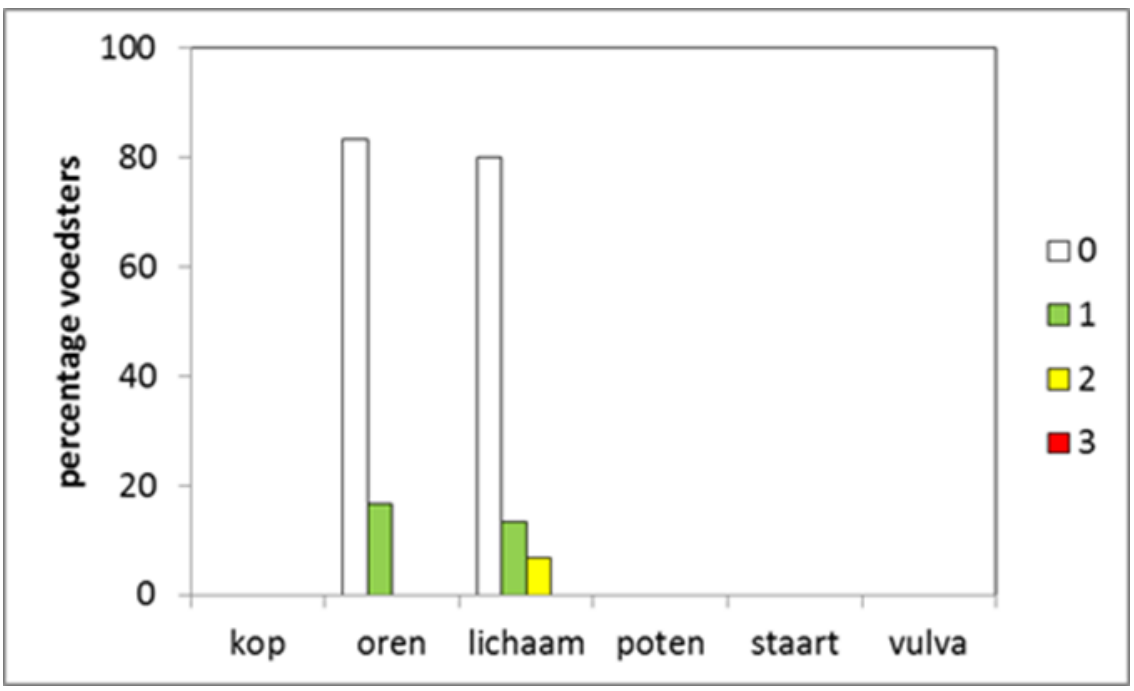

Figuur $7 \boldsymbol{b}$ Huidbeschadigingen 4 dagen na mengen in combiparken zonder nestkast-afscheidingen. ( 0 =geen, 1 =oppervlakkig, 2=matig, $3=$ open wonden.

\subsubsection{Uitval jongen}

De uitval van de jongen bleef beperkt en bedroeg $2 \%$ ( 7 jongen) verdeeld over de verschillende hokken. Hiervan zijn 2 jongen zijn verwijderd omdat ze te klein waren en 1 jong is preventief verwijderd omdat het pootbeschadiging had en 4 jongen hadden geen duidelijk omschreven oorzaak

\subsection{Conclusies}

1. In de hokken waarin de nestkastafscheidingen waren verwijderd, werden slechts lichte en enkele matige huidbeschadigingen aangetroffen, maar geen ernstig beschadigde voedsters. Mogelijk vormt de nestkasafscheiding toch een belemmering voor de voedsters om goed weg te kunnen komen wanneer ze aangevallen worden. De hokindeling speelt mogelijk toch een rol in het optreden van ernstige beschadigingen van voedsters.

2. De uitval onder de jongen bedroeg $2 \%$ en was laag. 


\subsection{Aanbevelingen voor verder onderzoek}

De laatste pilot suggereert dat het wegnemen van de tussenschotjes van de nestkasten gunstig werkt op het aantal beschadigingen. Uit een grotere proef met meer herhalingen zal moeten blijken of de nestkastafscheidingen en daarmee de hokindeling werkelijk van invloed is op de huidbeschadigingen en daarmee op de rangorde strijd tussen voedsters na mengen. 


\section{Referenties}

Kalle, 1994 Kalle G. Kaninchen in Gruppenhaltung. DGS 1994, 25: 16-20.

Rommers, J.M. ; Jong, I.C. de (2005). De haalbaarheid van groepshuisvesting voor voedsters in de praktijk. Lelystad : Animal Sciences Group, (Rapport / Animal Sciences Group 05/I02047) - 45

Rommers J.M., Gunnink H., Klop A., Jong, I.C. de , 2011. Analysis of dynamics of agression as a tool to improve group housing for rabbits does. In: Proceedings of the 5 th International Conference on the Assessment of Animal Welfare at Farm and Group Level, 08-11 August 2011, Guelph, Canada. - Guelph, Canada : Campbell centre for the Study of Animal Welfare, University of Guelph, 5th International Conference on the Assessment of Animal Welfare at Farm and Group Level, Guelph, 2011-08-08/2011-08-11 - p. 93 - 93.

Rommers, J.M. ; Kemp, B. ; Houwers, H.W.J. ; Gunnink, H. ; Jong, I.C. de (2012)Description of nestbox visits and suckling events in a group housing system for rabbit does as compared to individual cages. World Rabbit Science 20 (4). - p. 231 - 240. https://doi.org/10.4995/wrs.2012.1231

Rommers, Jorine M., Berry J.F. Reuvekamp, Henk Gunnink, Ingrid C.de Jong, 2014. Effect of hiding places, straw and territory on aggression in group-housed rabbit does. Applied Animal Behaviour Science, Volume 157, August 2014, Pages 117-126. 

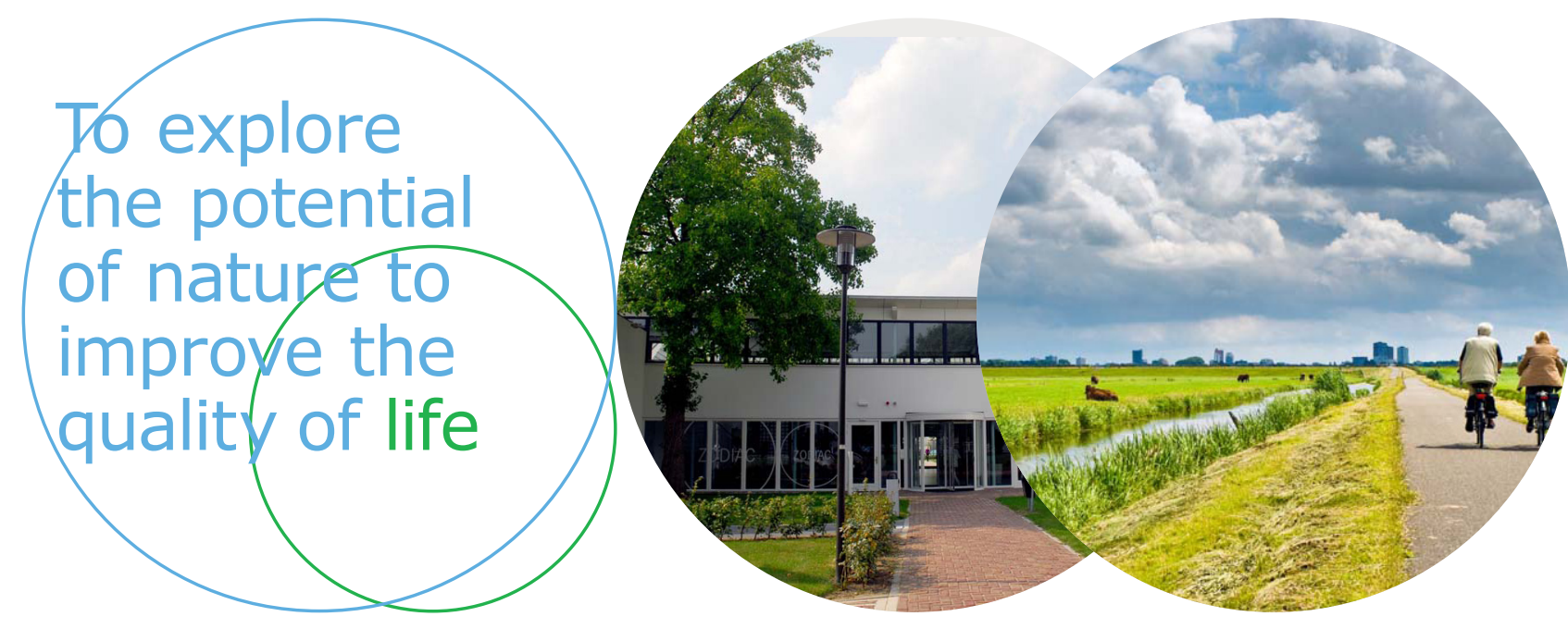

Wageningen Livestock Research Postbus 338

$6700 \mathrm{AH}$ Wageningen

T 0317483953

E info.livestockresearch@wur.nl www.wur.nl/livestock-research
Wageningen Livestock Research ontwikkelt kennis voor een zorgvuldige en renderende veehouderij, vertaalt deze naar praktijkgerichte oplossingen en innovaties, en zorgt voor doorstroming van deze kennis. Onze wetenschappelijke kennis op het gebied van veehouderijsystemen en van voeding, genetica, welzijn en milieu-impact van landbouwhuisdieren integreren we, samen met onze klanten, tot veehouderijconcepten voor de $21 \mathrm{e}$ eeuw.

De missie van Wageningen University \& Research is 'To explore the potential of nature to improve the quality of life'. Binnen Wageningen University \& Research bundelen 9 gespecialiseerde onderzoeksinstituten van Stichting Wageningen Research en Wageningen University hun krachten om bij te dragen aan de oplossing van belangrijke vragen in het domein van gezonde voeding en leefomgeving. Met ongeveer 30 vestigingen, 6.500 medewerkers en 10.000 studenten behoort Wageningen University \& Research wereldwijd tot de aansprekende kennisinstellingen binnen haar domein. De integrale benadering van de vraagstukken en de samenwerking tussen verschillende disciplines vormen het hart van de unieke Wageningen aanpak. 